\title{
Yerel Yöneticilerin Bölge Turizmine Yönelik Düşünceleri Üzerine Bir Araştırma: Artvin - Arhavi Örneği
}

\author{
Ceyhun Akyol ${ }^{1}$ \\ Burhanettin Zengin ${ }^{2}$ \\ Süleyman Akkaşoğlu ${ }^{3}$ \\ Şevki Ulema ${ }^{4}$
}

Yerel Yöneticilerin Bölge Turizmine Yönelik Düşünceleri Üzerine Bir Araştırma: Artvin - Arhavi Örneği

Öz

Çalışmanın amacı, Arhavi destinasyonunda faaliyet gösteren paydaşlardan olan yerel yöneticilerin yöre turizmi ile ilgili düşüncelerini belirlemek ve turizm endüstrisine olan katkılarını tespit etmektir. Doğu Karadeniz Bölgesi'nin eşsiz doğal, kültürel, tarihi ve turistik değerlere sahip Artvin ili Arhavi ilçesi yerel yöneticileri ile nitel araştırma yöntemi kapsamında yarı yapılandırılmış mülakat tekniği kullanılarak elde edilen veriler içerik analizi yoluyla değerlendirilmiştir. Araştırma sonuçlarına göre, Arhavi ilçesinde hizmet veren yerel yöneticilerin ve kurumlarının mevcut turizm faaliyetlerine katılımları ve turizm hareketlerine bakışlarının olumlu olduğu tespit edilmiştir. Diğer yandan, ilgili yönetici ve kurumların turizm endüstrisi ile ilgili faaliyetlerdeki eşgüdüm eksikliği belirlenmiş olup, var olan eksiklikler ve ilçe turizmi ile ilgili sorunlara çözüm önerileri getirilmeye çalışılmıştır. Ayrıca, yerel paydaşlara, turizm işletmelerine ve araştırmacılara destinasyon ile ilgili araştırma önerileri sunulmuştur.

Anahtar Kelimeler: Turizm Yönetimi, Yerel Yöneticiler, Doğu Karadeniz, Arhavi
A Research on Local Administrators' Thoughts about Region Tourism: Artvin - Arhavi Example

\section{Abstract}

The aim of the study is to determine the thoughts of local administrators, who are active in Arhavi destination, about tourism in the region and to determine their contribution to tourism industry. The data obtained by using the semi-structured interview technique within the scope of qualitative research method and the local managers of Arhavi district of Artvin province with unique natural, cultural, historical and touristic values of East Blacksea Region were evaluated through content analysis. According to the results of the research, it is determined that local administrators and institutions serving in Arhavi district have positive attitudes to tourism activities and participation in existing tourism activities. On the other hand, lack of coordination in activities related to tourism industry of relevant managers and institutions has been determined and efforts have been made to propose solutions to the problems related to the existing deficiencies and district tourism. In addition, local stakeholders, tourism enterprises and researchers have been offered research proposals for destinations.

Keywords: Tourism Management, Local Administrators, East Blacksea, Arhavi

\section{Giriş}

21. yüzyılın kalkınma anlayışında sosyal aktörler önceki dönemlere oranla daha fazla rol almaktadır. Bu aktörler arasında önemli bir yere sahip olan yerel yönetimler özellikle bölgesel kalkınmada etkin bir rol oynamaktadır. Bir bölge ile ilgili yapılacak planlama ve programlama uygulamalarını gerçekleştirebilme adına önemli rollere sahip olan yerel yönetimler, alınacak

\footnotetext{
${ }^{1}$ Dr., Artvin Çoruh Üniversitesi, Arhavi Meslek Yüksekokulu, ceyhunakyol@artvin.edu.tr, Yazar ORCID bilgisi: https://orcid.org/ 0000-0001-5542-7309

2 Prof. Dr., Sakarya Uygulamalı Bilimler Üniversitesi, Turizm Fakültesi, bzengin@subu.edu.tr, Yazar ORCID bilgisi: https://orcid.org/ 0000-0002-6368-0969

3 Dr., İstanbul Arel Üniversitesi, İktisadi ve İdari Bilimler Fakültesi, suleymanakkasoglu@arel.edu.tr, Yazar ORCID bilgisi: https:// orcid.org/0000-0003-0613-9743

${ }^{4}$ Doç. Dr., Sakarya Uygulamalı Bilimler Üniversitesi, Turizm Fakültesi, ulema@subu.edu.tr, Yazar ORCID bilgisi: https://orcid.org/ 0000-0002-5874-8797
} 
kararlar ve uygulanacak politikalar konusunda en iyi bilgiye sahip kurum ve kuruluşlardır (Jeffries, 2007: 53).

Günümüzde ekonomik büyümenin yanı sıra, sosyal gelişim ve sürdürülebilirlik anlayışı da önem kazanmaktadır. Bu gelişmeler içerisinde, özellikle modern toplumlar bünyesinde faaliyet gösteren yerel yönetimler önemli bir konuma sahiptir. Bölgesel ve yerel kalkınmada etkin ve verimli çalışmalar içerisinde bulunan yerel yönetimler, devlet kurumunun yetersiz kaldığı sorunlara temas ederek çözüm yaratma gayreti içerisinde bulunmaktadır (Küçük ve Güneş, 2013: 24).

Küçük ölçekli bölgeler ve bu alanlardan sorumlu yerel yöneticiler, sorumlu oldukları sınırlar içerisinde ekonomik bakımdan güçlü ve sürdürülebilir olmak için mevcut değerlerden faydalanmaya çalışmaktadır. Yerel yöneticiler için, hizmet ettikleri bölgelerdeki doğal, kültürel, tarihi ve turistik değerler o bölgelerin ekonomik güç ve tanınırlık kazanması açısından önemli etkenlerdir. Turizm açısından zengin bir birikime sahip olan destinasyonlar, planlı ve etkin bir turizm uygulaması ile bölgesel kalkınma ve dengeli gelişime de katkı sağlamaktadır (Albeni ve Ongun, 2005: 95).

Turizm ile ilgili plan ve politikalar merkezi yönetimler tarafından oluşturulmakta ve oluşturulan bu plan ve politikaların uygulama kısmını ise yerel yönetimler gerçekleştirmektedir (Kalaycıoğlu, 2017: 2). Dolayısıyla yerel olarak bir bölgede turizm endüstrisinin gelişiminde yerel yönetimlerin önemli bir rolü olduğu söylenebilir. Özellikle yerel yönetimlerin bölge turizmine bakış açıları, bulundukları bölgenin turizm potansiyeli hakkındaki düşünceleri ve bölgedeki turizm faaliyetlerinin gelişimine yönelik yapılabilecek uygulamalar hakkındaki düşüncelerinin ortaya çıkarılması, bölge turizminin gelişimi açısından son derece önem arz eden bir konudur.

Bu çalışmanın amacı, Arhavi ilçesindeki yerel yöneticilerin bölge turizmine bakış açılarının belirlenmesi ve bölge turizmine ilişkin yapılabilecek faaliyetleri ortaya koymaktır. Bu amaçla çalışmanın ilk bölümünde yerel yönetimler, turizm, yerel yönetimler ve turizm ilişkisi, Arhavi destinasyonu, destinasyondaki turizmin mevcut durumu ve konu ile ilgili çalışmalar başlıkları altında ilgili ulusal ve uluslararası literatüre yer verilmiştir. Çalışmanın son bölümünde ise, destinasyonda yer alan on iki yerel yöneticiyle gerçekleştirilen mülakatlar aracılığıyla elde edilen verilere ilişkin bulgular ile ulaşılan sonuç ve önerilere yer verilmiştir.

\section{Kavramsal Çerçeve}

Çalışmanın bu kısmında yerel yönetimler, turizm, yerel yönetimler ve turizm ilişkisi ile konu ile ilgili daha önce gerçekleşmiş araştırmalara yer verilmektedir.

\subsection{Yerel Yönetimler}

Merkezi yönetimlerin dışında kalan kamusal örgütlenmeler olan yerel yönetimler (mahallî idareler), yerel topluluklarının müşterek gereksinimlerinin yerinden belirlenmesi ve karşılanmasından sorumlu kesimdir. Kamu yönetiminin vatandaşa en yakından hizmet veren birimleri olan yerel yönetimlerin görev alanları yurttaşların gündelik yaşamda karşılaştıkları ana meseleleri içerir. Yerel yönetimler, görev yaptıkları alanlarda vatandaşlarla iletişim kurmakta üstün durumda olan ve kendilerine verilen vazifeler doğrultusunda iletişim kurmaları zaruriyet gösteren birimlerdir (Akay, 2016: 3).

Yörede yaşayan halkın yerel nitelikteki sosyal, demokratik, altyapı, planlama gibi hizmetlerini sağlayarak ortak ihtiyaçlarını karşılama amacıyla kurulan yerel yönetimler, destinasyon gelişiminde önemli bir rol oynamaktadır (Güler, 2017: 427). Yerel yönetimler, bölgesel ekonomiyi ve sosyal yaşamı desteklemekte, sürdürülebilir kalkınma doğrultusunda ekonomik, 
sosyal, çevresel ve siyasi yönde düzenlemeler gerçekleştirmekte, ayrıca var olan ulusal bir alt bölgeyi belirli ölçüde kontrol etmekte ve bu bölgede yaşayan insanları temsil etmektedir (Ulusoy ve Akdemir, 2017: 21; Mkhonta, 2007: 15).

Özellikle turizm bölgelerinin yönetiminde etkin bir biçimde rol alan yerel paydaşlar; mülki idare amirlikleri, yerel yönetimler, turizm işletmeleri, meslek birlikleri ve odalar, eğitim kurumları, turistler, turizm çalışanları, yerel halk ve sivil toplum kuruluşlarından oluşmaktadır (Türkay, 2014: 13).

Yerel yönetimlerin turizmle ilgili olan faaliyetlerini turizme yönelik ve turizmi etkileyen hizmetler olarak incelemek mümkündür (Gürsoy, 2006: 71). Turizme yönelik hizmetler; tanıtım, spor, kültür, sanat ve rekreasyon faaliyetlerinden oluşurken turizmi etkileyen hizmetler ise; planlama, denetim, peyzaj, park, temizlik, çevre düzenlemesi, imar, ulaşım, konut faaliyetlerinden oluşmaktadır.

Günümüz toplumunda yerel yönetimler; siyasal olgunluğun gelişmesi, demokratik anlayışın benimsenmesi ve ülke barışına katkı sağlamaları açısından önemli kuruluşlar olmakla birlikte bulundukları bölgeyi en iyi bilen merkezi yönetimin yerel organlarıdır (Tortop vd., 2014: 18). Ayrıca, bölgenin sahip olduğu sosyal, kültürel, ekonomik ve coğrafi özelliklere göre yatırım yapmak ve yatırımları teşvik etmek konusunda da etkin rol oynamaktadır (Kaya, 2009: 29).

\subsection{Turizm}

Turizm; insanların boş zamanlarını kıymetli hale getirmek maksadı ile maddi bir getiri elde etmeksizin ve siyasi etkinliklerde bulunmaksızın, münferit veya grup olarak yapılan seyahatlerde gidilen yerde asgari bir gün ya da bir konaklama yapılarak bu süre zarfında dinlenme, eğlenme, merak, spor, din, sağlık için gerçekleştirilen ziyaretler, kültürel etkinlikler, dost ve hısım ziyaret etme gibi faaliyetlerden en az birinin etkin hale getirilmesi ve bu süreç içinde ortaya çıkan gereksinimler ile temaslarını kendisine konu alan, sosyal, ekonomik ve kültürel bir faaliyet ve bir hizmet endüstrisidir (Akıllı, 2004: 18). Diğer bir tanıma göre turizm; "Insanların devamlı ikamet ettikleri, çalıştıkları ve her zamanki olağan ihtiyaçlarını karşıladıkları yerlerin dışına seyahatleri ve buralardaki, genellikle turizm işletmelerinin ürettiği mal ve hizmetleri talep ederek, geçici konaklamalarından doğan olaylar ve ilişkilerin bütünüdür" (Toskay, 1983: 39).

Dünya Turizm Örgütü (WTO) verilerine göre (Tablo 1), turizm hareketleri özellikle son altmış yılda hızla büyüme göstermiştir. 1950'li yıllardaki yirmi beş milyon olan turist hareketi 2000 yılında 674 milyona, 2015 yılında ise 1 milyar 186 milyona ulaşmıştır. Turizm gelirleri incelendiğinde ise; 1950 yılında 2 milyar dolar iken 2000 yılında 495 milyar dolar, 2015 yılında ise 1 trilyon 260 milyar dolarlık bir pastadan söz edilmektedir (UNWTO, 2016: 2). Bu büyüme 2030 yılı turizm hareketleri tahminlerine de yansımaktadır. Dünya Turizm Örgütü istatistiklerine göre uluslararası turist hareketleri 2030 yılında 1 milyar 800 milyon insana ulaşacaktır (UNWTO, 2016: 3).

Uluslararası turizm hareketleri ve turizm gelirlerinde artan rakamlar, yerel ekonomileri de etkilemektedir. Dünya genelinde artan turizm istatistikleri yerel ekonomilere gelişim imkânı ve istihdam fırsatları sağlamaktadır (UNWTO, 2017: 6). Yerel ekonomilere önemli oranda katkı sağlayan turizm hareketleri bölgesel kalkınma, planlama ve yönetim faaliyetlerini de önemli derecede etkilemekte ve ilgilendirmektedir.

Turizm endüstrisi, bölgesel/yerel kalkınma ve kaynakların dinamik bir biçimde kullanılması açısından oldukça önemli olmakla birlikte bölgesel istikrarsızlığı dindirme konusunda da faal 
bir rol oynamaktadır. Çünkü tarım ve sanayi endüstrilerinde yeterli kaynağa ve gelişme olanağına sahip olmayan bölgelerin, verimli turistik kaynaklarını planlı ve tesirli turizm politikası uygulamaları sonucunda turizm açısından istikrarlı bir biçimde kalkınmalarının sağlanması önem teşkil etmektedir (Çeken, 2008: 298).

Tablo 1: Türkiye Toplam Turizm Geliri ve Turist Sayıları

\begin{tabular}{cccc}
\hline Yıllar & Turizm Geliri (1000 \$) & Ziyaretçi Sayısı & Ortalama Harcama (\$) \\
\hline 2004 & 17.076 .606 & 20.262 .640 & 843 \\
2005 & 20.322 .112 & 24.124 .501 & 842 \\
2006 & 18.593 .951 & 23.148 .669 & 803 \\
2007 & 20.942 .500 & 27.214 .988 & 770 \\
2008 & 25.415 .067 & 30.979 .979 & 820 \\
2009 & 25.064 .482 & 32.006 .149 & 783 \\
2010 & 24.930 .997 & 33.027 .943 & 755 \\
2011 & 28.115 .692 & 36.151 .328 & 778 \\
2012 & 29.007 .003 & 36.463 .921 & 795 \\
2013 & 32.308 .991 & 39.226 .226 & 824 \\
2014 & 34.305 .903 & 41.415 .070 & 828 \\
2015 & 31.464 .777 & 41.617 .530 & 756 \\
2016 & 22.107 .440 & 31.365 .330 & 705 \\
2017 & 26.283 .656 & 38.620 .346 & 681 \\
\hline
\end{tabular}

Kaynak: Kültür ve Turizm Bakanlığı, 2018

2004-2017 yıllarına ilişkin turizm geliri ve turist sayıları incelendiğinde geçmişten günümüze turizm gelirleri ve turist sayılarında belli dönemlerde düşüşler yaşansa da genel olarak turizm gelirleri ve turist sayılarında artış olduğu söylenebilir. 2004 yılında 20 milyon 262 bin turist ve 17 milyar 76 milyon dolar turizm geliri elde edilirken, 2017 yılında 38 milyon 620 bin turist ve 26 milyar 283 milyon dolar turizm geliri elde edilmiştir. Ülkelere sağladığı ekonomik getirisi bu derece fazla olan turizm endüstrisinin ilgili destinasyonlarda geliştirilmesinde yerel yönetimlere önemli görevler düşmektedir.

Bölgesel gelişmenin sağlanmasında itici endüstrilerden biri olan turizm, bir yandan iktisadi kalkınmayı amaçlarken diğer yandan da tarih ve kültür alanlarının muhafaza ve restore edilmesine, çekiciliği olan ekolojik sahaların korunmasına önem verip kültürel sermayeye dikkat çekerek maziye olan ilgiyi de çoğaltmaktadır. Bu durum, destinasyona ziyaretçi çekmenin yanı sıra bölge halkının da kendi yöresine olan ilgi ve aidiyetini artırıcı bir etken olarak dikkat çekmektedir.

\subsection{Yerel Yönetimler ve Turizm Ilişkisi}

Turizm endüstrisi içerisinde birçok etkili aktör bulunmaktadır. Yerel yönetimler de bu aktörlerin en önemlilerindendir. Endüstri içerisinde faaliyet gösteren kurum ve kuruluşların çıkarlarını korumak ve yereli en iyi tanıyan paydaşlar olmaları bakımından yerel yönetimler endüstri içerisinde önemli bir konuma sahiptir (Dede ve Güremen, 2010: 58).

Turizm endüstrisinin içerdiği farklı konu ve sorunlar arasında yerel yönetimlerin uzlaşma ve denge kurabilmesinin yolu kapsamlı, bütüncül, paylaşımcı ve çok katılımlı bir yönetim anlayışından geçmektedir (Çekül, 2012: 8). Bu ilkeler çerçevesinde sağlanacak bir yönetim anlayışı destinasyona ilişkin geçici katkılardan ziyade uzun vadeli kazanımlar sağlayacaktır.

Bölge halkında turizm bilinci oluşturulması, turizmin çeşitlendirilmesi, altyapı ve üstyapı hizmetlerinin iyileştirilmesi, tanıtım ve pazarlama faaliyetlerine ağırlık verilmesi, nitelikli işgücü ve hizmet kalitesinin artırılması, yöresel el sanatları, organik gıda, hediyelik eşya üretimi gibi yerel ölçekli turizm ürünleri oluşturma konularında endüstriye katkı sağlayan yerel yöne- 
timler, yerel ölçekte turizmin geliştirilmesi adına katılımcı bir rol üstlenmektedir (Baycan, 2017: 449; Long, 1994: 21).

Günümüz yönetim anlayışı çerçevesinde turizm endüstrisi özellikle yerel yönetimlerin ilgi gösterdiği bir alan haline gelmiştir. Yerel kalkınmaya da doğrudan etkisi bulunan turizmle ilgili yerel yöneticilerin gerek kendi kurumlarınca gerekse de diğer kurumlarla birlikte eşgüdüm içerisinde yürüttükleri birçok çalışma bulunmaktadır. Kültür, sanat, spor, eğitim, çevre, sağlık gibi farklı disiplinlerle de desteklenen turizmle ilgili tanıtım ve iletişim konuları diğer kurumların da desteğiyle etkili bir biçimde gerçekleşmektedir. Ayrıca, bir bölgenin tümünü ilgilendiren eğitim, sağlık, spor, kültür ve turizm gibi alanlardaki hizmetlerin başarılı olabilmesi tüm paydaşların katılımına bağlıdır (Çetin, 2008: 130).

\subsection{Arhavi Destinasyonu}

Doğal güzellikleri, tarihi ve kültürel zenginlikleri, bozulmamış tabiatı yönünden Doğu Karadeniz Bölgesi'nin ve Artvin ilinin özellikle son yıllarda isminden bahsedilen bir destinasyonu olan Arhavi ilçesi (Şekil 1), sahip olduğu dağ, yayla, vadi, akarsu, göller dışında cami, kilise, köprü, kale, konut, serender gibi tescilli kültür varlıklarına da ev sahipliği yapmaktadır (Artvin Valiliği, 2018: 137).

Şekil 1: Arhavi İlçe Haritası

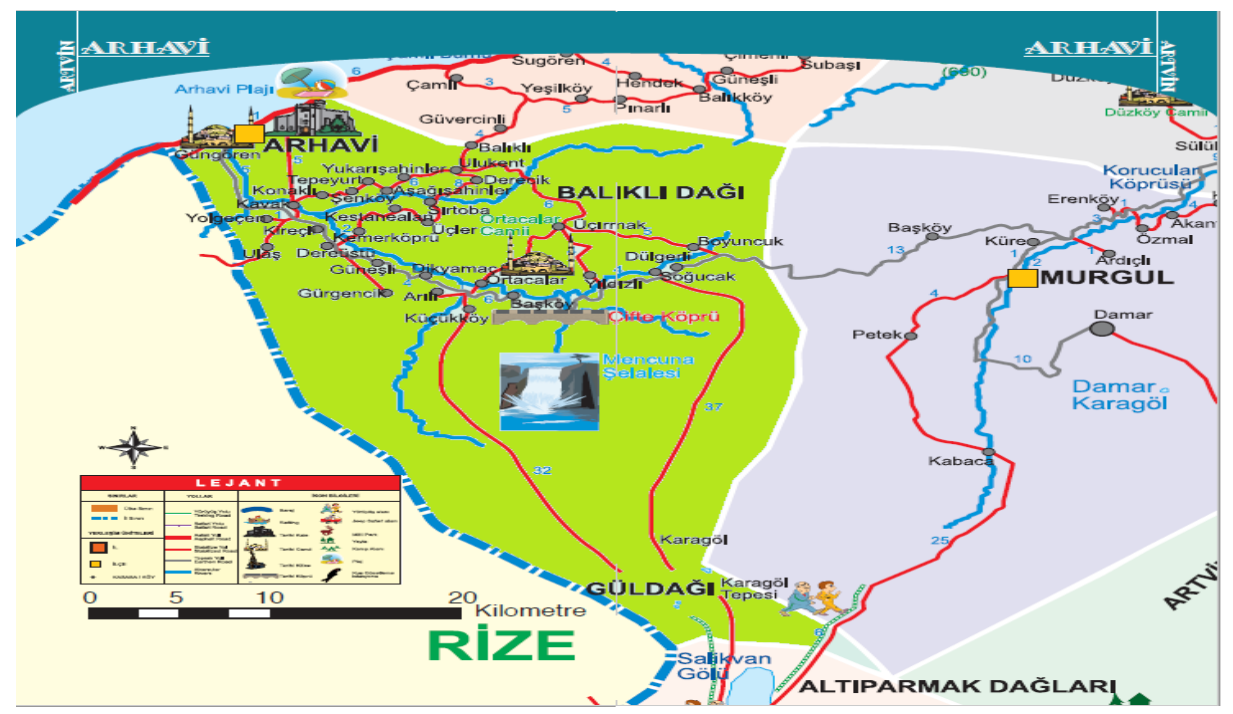

Kaynak: Artvin Valiliği, 2018: 34-35.

Otuz köy, yedi mahalleden oluşan ilçe yüzey şekilleri bakımından dağlık ve engebeli bir yapıya sahiptir (Özçakmak, 2014: 68). Daha çok kırsal bölgelerinde yetişen ve ilçe merkezinde işlenen çay ile balıkçılık, fındık ve kivi yetiştiriciliği ilçenin önemli geçim kaynaklarındandır (Özaydın, 2016: 199).

\subsection{Arhavi Destinasyonunda Turizmin Mevcut Durumu}

Doğu Karadeniz'in körfez kıyısına kurulan ilçede Cenevizlilerden kalma Ciha Gözetleme Kalesi, Mençuna Şelalesi, Çifteköprü, Ciha Dağı ve 1973 yılından beri gerçekleştirilen Uluslararası Arhavi Kültür ve Sanat Festivali, destinasyonun sahip olduğu turizm değerleri arasındadır. Merkez, Ulukent ve Ortacalar Camileri, Ortacalar Çifte Kemer, Orçi Deresi Kemer, Derecik Köyü Kemer, Aşağı Şahinler Köyü Kemer Köprüleri tescilli taşınmaz kültür varlıklarıdır. Ayrıca 
Dereüstü, Derecik ve Kavak Köylerinde tesis edilen Alabalık üretim çiftliği ve sosyal tesisleri rekreasyon alanlarıdır. Metruk kilise ile birlikte manzara açısından doyumsuz seyirle kayalık mevkiindeki Martı Kuşu Cenneti önemli tarihi, kültürel ve turistik noktalardır (Akyol, 2011: 4).

\subsection{Destinasyon Turizm Verileri}

Illçe ile ilgili turizm verileri; konaklama tesisleri, seyahat acentesi, kültür, sanat ve turizm derneği, tescilli kültür varlıkları, düzenlenen festival ve şenlikler başlıklarında incelenmiştir (Artvin II Kültür ve Turizm Müdürlüğü, 2018).

Tablo 2: Konaklama Tesisleri Envanteri

\begin{tabular}{|c|c|c|c|c|c|c|c|c|c|c|c|}
\hline \multirow{2}{*}{$\begin{array}{c}\text { Bakanlık } \\
\text { Belgeli } \\
\text { Tesis } \\
\text { Sayısı }\end{array}$} & \multirow{2}{*}{$\begin{array}{c}\text { Bakanlık } \\
\text { Belgeli } \\
\text { Oda } \\
\text { Sayısı }\end{array}$} & \multirow{2}{*}{$\begin{array}{c}\text { Bakanlık } \\
\text { Belgeli } \\
\text { Yatak } \\
\text { Sayısı }\end{array}$} & \multirow{2}{*}{$\begin{array}{c}\text { Mahalli } \\
\text { Belgeli } \\
\text { Otel } \\
\text { Sayısı }\end{array}$} & \multirow{2}{*}{$\begin{array}{l}\text { Mahalli } \\
\text { Belgeli } \\
\text { Otel Oda } \\
\text { Sayısı }\end{array}$} & \multirow{2}{*}{$\begin{array}{c}\text { Mahalli } \\
\text { Belgeli } \\
\text { Otel } \\
\text { Yatak } \\
\text { Sayısı } \\
\end{array}$} & \multirow{2}{*}{$\begin{array}{l}\text { Mahalli } \\
\text { Belgeli } \\
\text { Pansiyon } \\
\text { Sayısı }\end{array}$} & \multirow{2}{*}{$\begin{array}{c}\text { Mahalli } \\
\text { Belgeli } \\
\text { Pansiyon } \\
\text { Oda Sayısı }\end{array}$} & \multirow{2}{*}{$\begin{array}{c}\text { Mahalli } \\
\text { Belgeli } \\
\text { Pansiyon } \\
\text { Yatak } \\
\text { Sayısı }\end{array}$} & \multicolumn{3}{|c|}{$\begin{array}{c}\text { Destinasyon } \\
\text { Toplamı }\end{array}$} \\
\hline & & & & & & & & & $\begin{array}{l}\text { Tesis } \\
\text { Sayısı }\end{array}$ & $\begin{array}{l}\text { Oda } \\
\text { Sayısı }\end{array}$ & $\begin{array}{l}\text { Yatak } \\
\text { Sayıs }\end{array}$ \\
\hline- & - & - & 3 & 106 & 210 & 2 & 21 & 47 & 5 & 127 & 257 \\
\hline
\end{tabular}

Arhavi destinasyonunda faaliyet gösteren konaklama tesisleri envanteri ile ilgili bilgiler Tablo 2'de yer almaktadır. Tabloya göre, Artvin ilindeki toplam 119 olan tesis sayısının $\% 4,17$ 'si, toplam 2.319 olan oda sayısının \%5.57'si, toplam 4.741 olan yatak sayısının ise \%5,42'si Arhavi destinasyonunda yer aldığı görülmektedir. Artvin'in sahil kıyısına sahip ilçelerinden biri olan Arhavi için konaklama tesisi sayısının yeterli olmadığı görülmektedir. Tesis sayısının artırılması, istihdam edilecek personelin de nitelikli olması konularına eğilim gösterilmelidir. Bu amaçla, ilçede hizmet veren Artvin Çoruh Üniversitesi Arhavi Meslek Yüksekokulu ile ilgili kurumlar arasında ortak çalışmalar yürütülmeli, Turizm ve Seyahat Hizmetleri ile Turizm ve Otel İşletmeciliği programlarından ve görev yapan akademisyenlerden ilgili konularda yararlanılmalıdır.

Tablo 3: Seyahat Acentesi Envanteri

\begin{tabular}{cc}
\hline Acente Adı & Grubu \\
\hline Gobulu 08 Turizm & $\mathrm{A}$ \\
Lazona Travel Turizm & $\mathrm{A}$ \\
\hline
\end{tabular}

İlçede faaliyet gösteren seyahat acenteleri ile ilgili bilgilerin yer aldığı Tablo 3'e göre Artvin ilindeki toplam on yedi seyahat acentesinin ikisi, yani \%11,76'sı Arhavi ilçesinde hizmet vermektedir. Faaliyet gösteren acentelerin tüm seyahat acenteciliği hizmetlerini gerçekleştirme yetkisine sahip A Grubu özelliği taşımaları destinasyon için avantajdır. Fakat ilçede faaliyet gösteren acente sayısının yeterli olmadığı, seyahat acentelerinin nicel ve nitel anlamda sayılarının artırılması gerektiği, ilgili kurum ve kuruluşlarca ortak görüştür.

Tablo 4: Kültür, Sanat ve Turizm Derneği Envanteri

\begin{tabular}{ccccc}
\hline Kültür ve Turizm & Kültür ve Sanat & Kültür & Kültür, Sanat ve Turizm & TOPLAM \\
\hline 1 & 1 & 2 & 2 & 6 \\
\hline
\end{tabular}

Sivil toplum kuruluşları, ilgili destinasyonda turizm ile ilgili amaçları gerçekleştirmek, turizm alanında kamuoyunu yönlendirmek veya aydınlatmak için çalışan, gönüllülük esasına göre hareket eden organizasyonel yapılardır (Alyakut, 2007: 30). İlçede hizmet veren, türü "Kültür, Sanat ve Turizm Derneği" olan faal durumdaki sivil toplum kuruluşları sayıları Tablo 4'te yer almaktadır. Artvin ilindeki kültür, sanat ve turizm amaçı kurulan toplam kırk yedi dernekten altısı, yani \%12,77'si Arhavi ilçesinde faaliyet göstermektedir. Yerel halkın kendile- 
rini geliştirmelerine yönelik projeler geliştiren, gelir düzeyinde eşitsizliği giderici çalışmalar yapan, turizm ile ilgili konularda danışmanlık görevi üstlenen bu turizm temalı sivil toplum kuruluşlarının destinasyon ve yerel halk üzerinde sağlayabileceği olumlu etkileri artırmak da rolleri arasındadır (Simpson, 2008: 7).

Tablo 5: Tescilli Kültür Varlıkları

\begin{tabular}{ccccccc}
\hline Cami & Kilise & Kale & Köprü & Konut & Çeşme & TOPLAM \\
\hline 7 & 1 & 1 & 5 & 59 & 1 & 74 \\
\hline
\end{tabular}

Tablo 5'te Arhavi destinasyonunda yer alan tescilli kültür varlıkları ile ilgili bilgiler bulunmaktadır. Bu bilgilere göre, Artvin ilindeki toplam 337 adet tescilli kültür varlığının yetmiş dördü, yani \%21,96'sı Arhavi ilçesindedir. Tarih öncesi ve tarihi devirlere ait, bilim, din, kültür ve güzel sanatlarla ilgili, yer üstünde, yer altında ve su altındaki korunması gerekli taşınmaz varlıklar olan bu eserler, tarihi ve kültürel zenginliklere sahip olan Arhavi destinasyonu için de önemli değerlerdir (Arslan, 1990: 28). Destinasyondaki tescilli konutların fazlalığı, özellikle ev pansiyonculuğu hizmetine yönelik gelişmeler için altyapı imkânı sağlamaktadır.

Tablo 6: Düzenlenen Festival ve Şenlikler

\begin{tabular}{ccc}
\hline Ulusal & Uluslararası & TOPLAM \\
\hline 7 & 1 & 8 \\
\hline
\end{tabular}

Arhavi ilçesinde düzenlenen ulusal ve uluslararası festival ve şenliklerle ilgili bilgilerin yer aldığı Tablo 6'ya göre, Artvin ilinde düzenlenen toplam yetmiş beş adet festival ve şenliğin sekizi, yani \%5,33'ü Arhavi'de gerçekleştirilmektedir. Günümüzde, kentlerin turizm geliştirme stratejilerinin önemli bir özelliği haline gelen festival ve şenlikler; bölgelerin kentsel yeniden yapılanma ve ekonomik kalkınma planlamalarının da ayrılmaz bir parçasını oluşturmaktadır (Visser, 2007: 101). Bu açıdan, destinasyonda gerçekleşen festival ve şenliklerin destinasyona ekonomik, sosyal ve kültürel anlamda katkıları olmaktadır. Bu açıdan değerlendirildiğinde Uluslararası Arhavi Kültür ve Sanat Festivali'nin tanıtım, kültürel ve sanatsal işbirliği ve yöresel kalkınmaya önemli etkileri bulunmaktadır.

Ayrıca, ilçede hizmet veren Halk Eğitim Merkezi Müdürlüğü tarafından düzenlenen sepet örme, tulum yapma, taş bebek oluşturma gibi geleneksel sanat faaliyetlerinin kursları, hem kültürel geleneklerin devamının sağlanmasına hem de konuya ilgi gösteren yerli ve yabancı ziyaretçilerin destinasyonu tanımalarına katkıda bulunmaktadır.

\section{Konu ile Iilgili Araştırmalar}

Bir bölgedeki yerel yöneticilerin turizme bakış açıları ve bölge turizm paydaşlarının turistik hizmetlere olan yaklaşımları, bölgenin gelişimi ve kalkınması açısından önem arz eden konulardır. Bu çalışma, Arhavi destinasyonunun sahip olduğu tarihi, kültürel, sosyal ve turistik değerlerin bölgesel ve ulusal çapta tanınırlı̆̆ını tetkik eden, bu doğrultuda ilçede hizmet veren yerel yöneticilerin görüş ve önerilerine yer veren bir araştırmadır.

Ulusal ve uluslararası literatür incelendiğinde özellikle son yıllarda Arhavi destinasyonu genelinde yerel yönetim çalışmaları yeterli olmamakla birlikte, destinasyona yönelik özellikle turizm konusunu ele alan çalışmaların artışı tespit edilmiştir.

Artvin'in Arhavi ilçesinde bulunan Mençuna Şelalesini ziyaret edenlere yönelik yapılan araştırmada yirmi iki katılımcı ile görüşme gerçekleştirilmiştir (Yıldız ve Bektaş, 2019). Şelaleyi ziyarete gelenlerin özçekime yönelik algılarını ortaya koyma amacı güdülen araştırma netice- 
sinde aile ile zaman geçirme, sosyal paylaşım, hatıra biriktirme ve manzara gibi başlıkların katılımcılar açısından özçekim motivasyonu oluşturduğu belirlenmiştir.

Arhavi ilçesinde yer alan Kamilet Vadisinin florasının incelendiği araştırmalarda, vadinin oldukça zengin floristik içerdiği tespit edilmiştir (Alataş vd., 2018; Yüksel, 2016). Bu özelliğin destinasyona turistik, rekreatif ve estetik gibi değerler kattığı, ekosistemi ve ormancılığı olumlu etkilediği görüşleri belirtilmiştir.

Arhavi destinasyonundaki doğal turistik kaynaklar içerisinde önemli bir konumda yer alan Mençuna Şelalesini konu alan farklı bir çalışmada tanıtım ile koruma ve kullanma kriterleri doğrultusunda sürdürülebilir ekoturizm başlıkları üzerinde durulmuştur (Koday vd., 2015). Literatür desteği, arazi çalışmaları ve anket uygulaması ile yürütülen çalışma neticesinde halk, ürün, kalkınma, turist kavramları yerel başlığı çerçevesinde derlenmiş, bu kavramların destinasyona katkıları değerlendirilmiştir.

Arhavi destinasyonunun kırsal turizm potansiyelinin değerlendirilmesine yönelik gerçekleştirilen çalışmada, literatür taraması ve arazi araştırmalarına ek olarak ilçe köylerinden konuya hakim olduğu düşünülen kişilerle görüşmeler gerçekleştirilmiştir (Akyol vd., 2014). Elde edilen bilgilere dayanılarak Arhavi destinasyonunun turizm açısından değer taşıyan tarihi ve doğal yapıların konumlarının tespiti yapıımaya çalışılmıştır. Çalışma neticesinde destinasyonun kırsal turizm değerlerinin tespiti, tanıtımı, bilinirliğinin artırılması ve tüm bu düşünceler doğrultusunda yerli ve yabancı ziyaretçi hareketlerinin çoğalması amaçlanmıştır.

Arhavi ilçesindeki yerel paydaşların kırsal turizm tanıtım sürecinde aldıkları rollerle ilgili yapılan araştırmada yedi yerel turizm paydaşı ile görüşme gerçekleştirilmiştir (Aydın ve Selvi, 2012). Araştırma neticesinde destinasyon tanıtımında daha çok Belediye ve Turizm Derneği çalışmalarının ön planda olduğu, diğer paydaşların ise bu sürece pek fazla dahil olmadıkları belirlenmiştir.

Ulusal ve uluslararası literatürde Arhavi destinasyonuna yönelik turizm temalı çalışmalar incelendiğinde bölgedeki yerel yöneticilerin turizm ile ilgili görüşlerine, düşüncelerine ve değerlendirmelerine, çalıştıkları kurumların bölge turizmine olan katkılarına yer verilirken, ayrıca bölge turizminin gelişimine yönelik neler yapılabileceği üzerinde de durulmuştur.

Diğer yandan, ulusal ve uluslararası literatürde araştırma alanı ve konusu ile ilgili çok fazla çalışma mevcut değildir. Yerel yöneticilerin turizm endüstrisine bakış açısını belirlemeye ve bölge turizminin gelişimine ilişkin yapılabilecek konuları bir arada ele alan çalışmalara az rastlanılması, ayrıca Arhavi destinasyonu özelinde daha önce araştırma konusu ile ilgili bir çalışmanın yapılmamış olması araştırmanın özgün taraflarını ortaya koymaktadır.

\section{Materyal ve Yöntem}

Araştırma alanı olarak, son yıllarda hem yerel yönetim anlayışının geliştiği gözlemlenen, hem de il turizm endüstrisinin geliştiği Artvin'in ilçelerinden, il merkezine $80 \mathrm{~km}$ uzaklıktaki Arhavi ilçesi seçilmiş olup, katılımcı olarak da ilçede görev yapan yerel yöneticiler tercih edilmiştir. Araştırmada, çalışma alanı olarak belirlenen Arhavi ilçesindeki yerel yöneticilerin turizm ile ilgili görüşleri alınmış, düşünceleri değerlendirilmiş, kendilerinin ve çalıştıkları kurumların ilçe turizmindeki fonksiyonları üzerinde durulmuş ve destinasyonda turizmin geliştirilmesi konusundaki önerilerine yer verilmiştir.

Araştırmada nitel araştırmalardaki amaçlı örnekleme yöntemlerinden olan maksimum çeşitlilik örnekleme yöntemi kullanılmıştır. Seçilen örnekleme yönteminde temel amaç, küçük bir örneklem oluşturarak araştırılan probleme ilgi gösteren, problemin içerisinde yer alan kişilerin 
çeşitliliğinden maksimum derecede yararlanmak yoğun olarak çalışılacak küçük bir örneklem içindeki bir olgunun çeşitliliğini yakalayabilmektir (Bozok vd., 2014: 23; Rubin ve Babbie, 2009: 150).

Turizm açısından gelişme gösteren Arhavi destinasyonunda, özellikle son yıllarda Doğu Karadeniz Bölgesine ve ilçeye olan yerli ve yabancı turistlerin ilgisi neticesinde turizmle ilgili faaliyet ve gelişmelerin artmasını sağlamıştır. Bu konularda bilgi edinebilmek için ilçe yöneticileri ile farklı tarihlerde saha çalışması gerçekleştirilmiştir. Araştırmada, sosyal bilimlerde yaygın olan nitel araştırma yöntemlerinden derinlemesine mülakat tekniği kullanılmıştır. Görüşenin ve görüşmecinin yüz yüze, telefon veya görüntülü, sesli ve resimli iletişim araçlarıyla gerçekleştirdiği bir veri toplama yöntemi olan mülakat, sorulan sorulara veya konulara, katılımcının kendi cevaplarını belirlediği bir görüşme tekniğidir (Erkuş, 2009: 117; Karasar, 2009: 165; Gillham, 2005: 3). Görüşme tekniği, nitel araştırmalarda, farklı ölçek yapılarında kullanılabilen (yapılandırılmış, yarı yapılandırılmış, yapılandırılmamış) ve derin derin bilgi edinilmesini sağlayan önemli bir nitel veri toplama araçlarından biridir (Mil, 2007: 3).

İlgili literatür taraması yapıldıktan sonra konu ile ilgili uzman görüşleri de alınarak yarı yapılandırılmış mülakat formu hazırlanmış olup, yerel yöneticilere bu formda yer alan sorular yöneltilmiştir. Yarı yapılandırımış mülakatlarda, araştırmacı katılımcı ile görüşme yapmadan önce araştıracağı ya da soracağı soruları belirleyip görüşme esnasında katı bir biçimde bu sorulara bağlı kalmasa da hazırladığı soruları rehber olarak kullanmaktadır (Şencan, 2005: 539).

Sakarya Üniversitesi, Artvin Çoruh Üniversitesi ve İstanbul Arel Üniversitesi'nde konu ile ilgili akademisyen görüşlerinin de alındığı sorular görüşme yöntemine uygun olarak düzenlenmiştir. Mülakat soruları ilgili literatür ve konu ile ilgili akademisyenlerin görüşlerinin alınması neticesinde araştırmacılar tarafından oluşturulmuştur. Araştırmanın verileri, 02.01.2017 30.01.2017 tarihleri arasında ilgili kişilerle yapılan mülakatlar sonucunda elde edilmiştir. Mülakatlar esnasında yerel yöneticilerin izinleri dâhilinde ses kaydı yapılmış ve gerekli görülen yerlerde notlar tutulmuştur. Görüşmeler ortalama 20 ila 30'ar dakika aralığında, toplam 335 dakika kayıt altına alınmıştır. Toplanan veriler literatür desteği ile değerlendirilmeye çalışıımıştır. Değerlendirmeler yapılırken elde edilen verilerin özgün orijinal formuna mümkün olduğu kadar sadık kalınmaya çalışıımıştır. Böylece toplanan veriler betimsel bir yaklaşım ile gerek görüldüğü yerlerde doğrudan alıntı yapılarak aktarılmıştır.

Katılımcıların destinasyon ve destinasyondaki turizm faaliyetleri hakkındaki görüşlerini en yalın hali ile öğrenmek adına soruların yanıtları için, elde edilen verilerden yararlanarak sistematik ve tarafsız sonuçlar çıkarmak üzere kullanılan içerik analizi yöntemi uygulanmıştır. İçerik analizinde amaç, elde edilen verileri açıklayabilecek kavramlara ve ilişkilere ulaşmaktır. Betimsel analizde özetlenen yorumlanan veriler, içerik analizinde daha derin bir işleme tabi tutulur ve betimsel yaklaşımla fark edilemeyen kavram ve temalar içerik analizi ile keşfedilebilir. İçerik analizinde temel olarak yapılan işlem, birbirine benzeyen verileri belirli kavramlar ve temalar çerçevesinde bir araya getirmek ve bunları okuyucunun anlayabileceği şekilde yorumlamaktır (Yıldırım ve Şimşek, 2011: 227; Koçak ve Arun, 2006: 22).

Mülakatların gerçekleştirildiği yerel yöneticiler; kaymakam, belediye başkanı, emniyet müdürü, gençlik hizmetleri ve spor müdürü, ticaret ve sanayi odası başkanı, esnaf ve sanatkârlar odası başkanı, folklor kültür ve turizm derneği başkanı, doğa koruma yayla turizm geliştirme derneği başkanı, meslek yüksekokulu müdürü, yerel gazete sahibi, meslek yüksekokulu müdü- 
rü, müdür yardımcısı ile meslek yüksekokulu turizm ve seyahat hizmetleri program koordinatöründen oluşmaktadır.

Yerel yöneticilerin bölge turizmi ile ilgili görüşleri ana temasıyla yapılan araştırma kapsamında katılımcılara yöneltilen sorular şu şekilde sıralanmaktadır:

$>$ Arhavi ilçe ekonomisinde turizmin yeri ve önemi hakkında ne düşünüyorsunuz?

$>$ Insanlar Arhavi destinasyonuna turizm amaçlı, seyahat amaçlı ya da gezi amaçlı neden gelsin, niçin tercih etsin?

> Sizce il, bölge hatta ülke genelinde Arhavi destinasyonu turizm açısından hak ettiği yerde midir ya da nerelerde olmalıdır?

$>$ Arhavi turizmi ile ilgili bir SWOT ${ }^{5}$ analizi yaptığınızda öne çıkan başlıklar nelerdir?

> Kurumunuz Arhavi'deki turizm faaliyetleri kapsamında bugüne dek neler yapmıştır? Günümüzde neler yapmaktadır? Gelecekte neler yapmayı hedeflemektedir?

> Arhavi'deki turizm değerlerini kişisel ve kurumsal açıdan ne kadar tanıyorsunuz? Gezdiğiniz ve gördüğünüz yerlerden örnekler verir misiniz?

\section{Bulgular ve Yorum}

Çalışmanın değerlendirilme aşaması neticesinde ulaştığımız bulgular, ilçede hizmet veren yerel yöneticilerin ilçe turizmi ile ilgili görüş ve önerilerinden oluşmaktadır. Arhavi destinasyonunda görev yapan yerel yöneticilere yöneltilen toplam altı soru mülakat yöntemiyle elde edilmiş olup, alınan yanıtlar ve görüşler sırasıyla derlenmiş ve tablo haline getirilmiştir. Görüşmeler sonucu elde edilen verilerin analiz aşamasında katılımcılar K1 ve sırasıyla kodlanmıştır. Bu sıralama ilçe mülki idare amirinden başlamaktadır.

Tablo 7: Katılımcıların Profili

\begin{tabular}{ccc}
\hline Katılımcı & Kurum/Kuruluş & Görevi \\
\hline K1 & Kaymakamlık & Kaymakam \\
K2 & Belediye & Başkan \\
K3 & Emniyet Müdürlüğü & Müdür \\
K4 & Gençlik Hizmetleri ve Spor Müdürlüğü & Başkan \\
K5 & Ticaret ve Sanayi Odası \\
K6 & Esnaf ve Sanatkârlar Odası & Başkan \\
K7 & Folklor Kültür ve Turizm Derneği & Başkan \\
K8 & Doğa Koruma Yayla Turizm Geliştirme Derneği \\
K9 & Meslek Yüksekokulu & Başkan \\
K10 & Yerel Posta Gazetesi & Sahibi \\
K11 & Meslek Yüksekokulu & Müdür Yardımcısı \\
K12 & Meslek Yüksekokulu & Bölüm Başkanı \\
\hline
\end{tabular}

Araştırmaya katkı sağlayan katılımcılar Tablo 7'de görüldüğü üzere; ilçe kaymakamı (K1), ilçe belediye başkanı (K2), ilçe emniyet müdürü (K3), ilçe gençlik hizmetleri ve spor müdürü (K4), ilçe ticaret ve sanayi odası başkanı (K5), ilçe esnaf ve sanatkârlar odası başkanı (K6), ilçe folklor kültür ve turizm derneği başkanı (K7), ilçe doğa koruma yayla turizm geliştirme derneği başkanı (K8), ilçe meslek yüksekokulu müdürü (K9), ilçe yerel posta gazetesi sahibi (K10), ilçe meslek yüksekokulu müdür yardımcısı (K11) ile ilçe meslek yüksekokulu turizm ve seyahat hizmetleri bölümü başkanından (K12) oluşmaktadır.

\footnotetext{
${ }^{5}$ Strenghts, Weaknesses, Opportunities, Threats (Güçlü Yönler, Zayıf Yönler, Fırsatlar, Tehditler)
} 
Katılımcıların ilçe ekonomisinde turizmin yeri ve önemi hakkındaki değerlendirmelerde ön plana çıkan başlıklar Tablo 8'de görülmektedir. Genel bir değerlendirme yapıldığında, katılımcıların ilçede turizm ile ilgili olanakların yetersizliği (K1, K3, K4, K6, K9, K10, K11) düşüncesi ön plana çıkmaktadır.

Tablo 8: Illçe Ekonomisinde Turizmin Yeri ve Önemi

\begin{tabular}{cr}
\hline Katılımc & Değerlendirme \\
\hline K1 & Mevcut olanaklar yetersiz, ileride gelişebilir. \\
K2 & Yeni kullanılmaya başlayan önemli bir iktisadi girdidir. \\
K3 & Herhangi bir katkısı bulunmamaktadır, doğal yaşam korunduğu sürece katkı sağlayacaktır. \\
K4 & $\begin{array}{r}\text { Potansiyel vardır, mevcut olanaklar yetersizdir. } \\
\text { K5 }\end{array}$ \\
K6 & Turizm hareketleri ve bilinci yeni yeni oluşmaya başlamış olup, zaman \\
K7 & içerisinde daha iyi yerlere gelecektir. \\
K8 & Ekonomiye çok fazla katkısı yoktur, turizm hareketlerinden esnaf yararlanamamaktadır. \\
K9 & Hak ettiği yerde değildir, özellikle ekoturizm potansiyeli mevcuttur. \\
K10 & Yerel halk için önemli bir gelir potansiyelidir. \\
K11 & Mevcut turizm işletmeleri yetersiz olup, tarım endüstrisi ön plandadır. \\
K12 & Mevcut olanaklar ile altyapı ve üstyapı faaliyetleri yetersizdir. \\
& Turizmin ekonomideki payı yetersizdir, mevcut çalışmalar yerelde kalmaktadır. \\
\hline
\end{tabular}

Turizmin ilçe ekonomisine sonraki dönemlerde önemli katkı sağlayacağı düşüncesi, katılımcıların (K1, K3, K4, K5, K7, K8, K12) paylaştığı diğer ortak bir kanıdır. Ayrıca yerel yöneticilerin büyük çoğunluğu bölgede bir turizm potansiyelinin olduğu fakat bu potansiyelin henüz yeterince değerlendirilemediği için turizm endüstrisinin bölge için ekonomik bir katkısının olmadığı görüşündedir. Bununla birlikte yerel yöneticilerden biri (K9), bölgede turizmden ziyade tarımın ön planda olduğunu belirtmiştir.

Katılımcıların görüşleri değerlendirildiğinde, bölgenin ekonomik olarak turizmden yeterince yararlanamadığı bunun da en önemli sebeplerinden birinin turizm endüstrisi ile ilgili olanakların yeterli olmaması olarak görüldüğü söylenebilir.

Turizmin ilçe ekonomisindeki yeri ve önemi ile ilgili bazı katılımcı görüşleri şu şekildedir:

K5 "Arhavi destinasyonu özellikle Doğu Karadeniz turizminin ulaşım ve geçiş noktalarının en can alıcı yerinde konumlanmaktadır. Destinasyonun bu özelliği, bölge turizmi kapsamında farklı pazarlama stratejileri ile değerlendirilmelidir."

K7 "Artvin il geneline bakıldığında tescilli kültür varlıklarının en yoğun olduğu destinasyonuz. Lakin, ürün-fayda stratejisi doğrultusunda optimum kâr getirini henüz görememekteyiz."

Yerli ve yabancı ziyaretçilerin Arhavi destinasyonunu tercih etme sebepleri konusunda katılımcıların değerlendirmeleri Tablo 9'da yer almaktadır. Destinasyonun tercih edilme sebepleri olarak katılımcıların ön plana çıkardığı özellikler; bozulmamış doğal yapı (K2, K3, K7, K10, K11), yeşil alanlar (K4, K5, K8, K9, K11) ve sakinlik (K4, K5, K6, K10, K11) olmuştur.

Tablo 9: Yerli ve Yabancı Ziyaretçilerin Destinasyonu Tercih Etme Sebepleri

\begin{tabular}{cc}
\hline Katılımcı & Değerlendirme \\
\hline K1 & Doğal yaşam, coğrafya, kuş gözlemciliği \\
K2 & Önemli ve keşfedilmemiş turizm arzları \\
K3 & Bozulmamış doğal yapısı, panoramik manzaralar \\
K4 & Yeşil alanlar, doğa ve yayla turizmi, sessizlik, sakinlik, huzur \\
K5 & Mavi ile yeşilin birleştiği yer, sakinlik, huzur \\
K6 & Dinlenmek, temiz hava, doğal yaşam \\
\hline
\end{tabular}




\begin{tabular}{cc}
\hline K7 & El değmemiş alanlar, tarihi ve kültürel mekânlar, yerel halkın misafirperverliği \\
K8 & Yayla ve ekoturizm faaliyetleri, ev pansiyonculuğu seçenekleri \\
K9 & Yeşil alanların çeşitliliği, doğa turizmi kaynakları \\
K10 & Doğası ile keşfedilmemiş tarihi ve kültürel değerleri \\
K11 & El değmemiş doğa, kırsal alanlar \\
K12 & Bölge ulaşımındaki önemli konumu, etkili destinasyonlara olan yakınlı̆̆ı \\
\hline
\end{tabular}

Yerel yöneticilere göre Arhavi destinasyonunun yerli ve yabancı turistler tarafından tercih edilmesinin en önemli nedenleri bölgenin kırsal turizm potansiyeli ve zengin bir doğal yapıya sahip olmasıdır. Özellikle destinasyona ilişkin yerel yönetimlerin üzerinde fikir birliği sağladığı nokta, bölgenin kültürel, tarihi ve doğal zenginliklere sahip olması ve bu durumun yerli ve yabancı turistlerce bölgeyi tercih etme nedeninin olmasıdır.

Yerli ve yabancı ziyaretçilerin destinasyonu tercih etme sebepleri ile ilgili bazı katılımcı görüşleri şu şekildedir:

K3 "il/çemiz, huzur ve güven sağlayan bir pozisyondadır. Dışarıdan gelen ziyaretçilerin ilçemizi en çok tercih etmelerinin başında bu iki faktör gelmektedir."

K10 "illçe turizmi gelişme kaydetmektedir. Tanıtım ile ilgili yetersizlikler bilinmekle birlikte, batı merkezli tur düzenleyen işletmelerin turlarında ilçemizin yer aldığını yavaş yavaş görmek bizlere mutluluk vermektedir. Bu gelişme, potansiyel yerli ve yabancı turistlerin destinasyonu tercih etmelerini sağlayacaktır."

Illçe turizminin mevcut durumu ile ilgili katılımcı görüşleri Tablo 10 'da değerlendirilmiştir. Katılımcıların ortak düşünceleri; destinasyonun turistik anlamdaki mevcudiyetinin yeterli olmadığı $(K 3, K 5, K 6, K 10, K 11)$, ilçe turizmi ile ilgili tanıtımın yetersiz olduğu $(K 3, K 4, K 7, K 10)$ ve yerel paydaşlar arasında uyum sorunu yaşandığı $(K 6, K 8, K 11, K 12)$ yönündedir.

\section{Tablo 10: Il/çe Turizminin Mevcut Durumu}

\begin{tabular}{|c|c|}
\hline Katılımcı & Değerlendirme \\
\hline K1 & İlin diğer ilçelerine oranla daha fazla tanınmaktadır. \\
\hline K2 & $\begin{array}{l}\text { Huzurlu, çağdaş, uygar ve eğitimli bir toplum olarak ilçede turizm bilinci oluşmaya başlamış olup, } \\
\text { daha fazla talep beklenmektedir. }\end{array}$ \\
\hline K3 & Hak ettiği yerde değildir. Tanıtım faaliyetlerinin artması ile turizmde daha iyi yerlere gelecektir. \\
\hline K4 & Tanıtım yetersizliği yaşanmaktadır. \\
\hline K5 & $\begin{array}{c}\text { Hak ettiği yerde olmamakla birlikte, konaklama ve ulaşım konularında çalışmalar } \\
\text { yapılması şartıyla ileriki zamanlarda daha iyi olacaktır. }\end{array}$ \\
\hline K6 & Hak ettiği konumda değildir. Yerel halkla birlikte esnafa da konu ile ilgili vazifeler düşmektedir. \\
\hline K7 & Daha fazla tanınmaya ihtiyaç duyulmaktadır. \\
\hline K8 & $\begin{array}{c}\text { Yerel yönetimlerin turizme olan ilgisi olmakla birlikte koordinasyon eksikliği turizm faaliyetlerine } \\
\text { olumsuz yansımaktadır. }\end{array}$ \\
\hline K9 & $\begin{array}{c}\text { Gürcistan ile ülkemiz arasındaki Sarp Sınır Kapısı'na olan yakınlık potansiyel yabancı turistler açı- } \\
\text { sından bir fırsattır. }\end{array}$ \\
\hline K10 & Komşu destinasyonlara nazaran (Ayder, Uzungöl) geri planda kalınmıştır. \\
\hline K11 & $\begin{array}{l}\text { Turizm endüstrisi ile ilgili yatırımlar yetersiz, konu ile ilgili kurumlar sınırlı sayıdadır. Sanayi ve } \\
\text { ticaretin sınırlı olması turizmi de etkilemektedir. }\end{array}$ \\
\hline K12 & $\begin{array}{c}\text { Kurum ve kuruluşlar arasında eşgüdüm eksikliği söz konusu olup, destinasyon } \\
\text { mevcut turlarda yeteri kadar yer almamaktadır. }\end{array}$ \\
\hline
\end{tabular}

Tablo 10 incelendiğinde özellikle bölgenin turizm açısından şu an hak ettiği noktada olmadığı, ilin diğer ilçelerine oranla daha fazla tanınmasına rağmen komşu bölgelerdeki destinasyonlara (Ayder, Uzungöl) oranla geri planda kaldığı, bölgenin ulaşım ve konaklama imkânları açısından yeterli olmadığı vurgulanmaktadır. Ağırlıklı olarak mevcut durumun turizm açısından yeterli olmadığı görüşü hâkim olsa da yerel yöneticilere göre yapılacak yatırımlar, pazarlama 
faaliyetleri ve kurumlar arası iletişimin geliştirilmesiyle bölge turizminin ilerleyen yıllarda daha iyi bir noktada olacağı görüşünün de hâkim olduğu söylenebilir.

ilçe turizminin mevcut durumu ile ilgili bazı katılımcı görüşleri şu şekildedir:

K4 "Destinasyondaki en mevcut durum tanıtım faaliyetlerindeki eksikliklerdir. Konu ile ilgili kişi, kurum ve kuruluşların bu konudaki adımlarının yöreselden ziyade, bölgesel, ulusal hatta uluslararası boyutlara taşınması gerekmektedir."

K8 "ilçemizde faaliyet gösteren tüm kurum ve kuruluşların ve yetkililerinin turizme ilgi gösterdikleri aşikârdır. Fakat bu ilginin uygulama safhasında etkin ve verimli bir hal alması gerekmektedir."

Katılımcıların destinasyon ile ilgili SWOT analizi değerlendirmeleri Tablo 11'de yer almaktadır. SWOT analizi bir olgunun hem iç hem dış alanlarının güçlü ve zayıf yönleri ile fırsat ve tehdit özelliklerini araştıran bir analiz tekniğidir (Böhm, 2008: 2). Buna göre, ilçe turizmi ile ilgili en güçlü özelliğin bozulmamış doğa $(K 2, K 3, K 5, K 6, K 9, K 12)$ olduğu, zayıf özelliklerin ise yerel paydaşların koordinasyon eksikliği $(K 2, K 7, K 8, K 9)$ ile tesis eksikliği $(K 1, K 5, K 12)$ olduğu göze çarpmaktadır.

Tablo 11: Illçe Turizmine Yönelik SWOT Analizi

\begin{tabular}{cc}
\hline Katılımcı & Değerlendirme \\
\hline K1 & S: Festival, şenlik, fotoğrafçılık W: Turizm tesisleri \\
K2 & $\begin{array}{c}\text { S: Doğal güzelliğin bozulmamış olması, geleneksel yaşam W: Yerel değerlere yerel halkın } \\
\text { bakışının tam olarak gelişmemesi, uygun yatırım arazilerinin yerel halk tarafından ulusal çapta } \\
\text { paylaşılmak istenmemesi O: Altyapıların yenilenmesi ve ulaşım olanaklarının artması }\end{array}$ \\
K3 & S: Bozulmamış doğa W: Turizm arzlarına olan ulaşım sorunları O: Rekreasyon potansiyeline \\
K4 & sahip alanların çokluğu \\
K5 & S: Deniz ve doğa potansiyeli W: Aşırı yağmur, konaklama işletmesi eksikliği, turizm değerlerine olan ulaşım \\
K6 & sıkıntısı O: Potansiyel alternatif turizm faaliyetleri \\
K7 & S: Bakir doğa W: Tanıtım ve reklam eksikliği
\end{tabular}

S: Strengths (Güçlü Yönler), W: Weaknesses (Zayıf Yönler), O: Opportunities (Fırsatlar), T: Threats (Tehditler)

Katılımcıların düşüncelerine göre potansiyel turizm türleri ilçe turizmi açısından fırsat olarak değerlendirilirken (K3, K4, K5, K10), kişisel ve kurumsal sorunların ilçe turizmine yönelik tehdit oluşturduğu $(K 7, K 8, K 12)$ belirtilmektedir.

İlçe turizmine yönelik SWOT analizi ile ilgili bazı katılımcı görüşleri şu şekildedir:

K1 "ilçemizin en önemli sunumu ulus/ararası boyutu bulunan geleneksel festivaldir. Turizm tesislerin nicelik ve nitelik konularındaki eksiklikleri ise destinasyonun eksik yönleridir." 
K6 "ilç̧emizin sahip olduğu bakir doğanın yanı sıra, doğal, kültürel ve sanatsal değerler de destinasyonu diğer turizm yörelerine göre öne çıkartabilecek etkenlerdir. Diğer yandan tanıtım ve reklam konularındaki eksiklikler, ilgili kişi ve kurumlarca mutlaka değinilmesi gereken konulardır."

Tablo 12' de katılımcıların bağlı bulunduğu kurum ve kuruluşların ilgili destinasyona yönelik turistik katkıları değerlendirilmektedir. Buna göre, yerel paydaşların daha çok destinasyonun tanıtılması ile ilgili çalışmalarda yer aldıkları (K2, K4, K5, K6, K7, K8, K10), ayrıca turizm eğitimi konusuna önem verdikleri (K2, K5, K8, K9, K11, K12) tespit edilmiştir.

\section{Tablo 12: Yerel Yönetimlerin Destinasyon Turizmine Yönelik Katkıları}

\begin{tabular}{cc}
\hline Katılımcı & Değerlendirme \\
\hline K1 & Mevcut binaların, evlerin ve diğer değerlerin restorasyon çalışmaları \\
K2 & İlçedeki tüm faaliyetlerde yürütücü ya da iştirakçi olma gayreti \\
K3 & Turizm değerlerine sahip çıma, yaşanabilecek hasarlar ya da verilebilecek zararlara karşı önlem alma \\
K4 & Sportif amaçı gelen misafirlere ilçenin önemli turizm değerlerinin tanıtılması \\
K5 & Yerel paydaşlarla koordineli bir biçimde çalışma \\
K6 & Üyelerin yerli ve yabancı misafirlere karşı ilgili ve hoşgörülü davranması \\
K7 & Bitirilme aşamasındaki yayla yol bağlantıları çalışmaları, keşfedilmemiş değerleri turizme kazandırma \\
K8 & faaliyetleri \\
K9 & Alternatif turizm faaliyetlerinin tanıtımını ve bilinilirliğini sağlama çalışmaları, \\
K10 & destinasyon ile ilgili ulusal ve uluslararası proje faaliyetleri \\
K11 & Seyahat hizmetleri ve otel işletmeciliği alanlarında verilen \\
K12 & eğitim-öğretim faaliyetleri \\
& Bilgilendirme ve reklam çalışmaları, turizm değerlerinin tanıtılması \\
& Nitelikli ve eğitimli işgücü yetiştirme faaliyetleri \\
& Kurum eğitmenlerinin bölgesel ve ulusal projelerde yer alması, yerel etkinliklere \\
& destek verilmesi, yerel halkın ve öğrencilerin katılım sağladığı geziler düzenlenmesi
\end{tabular}

Bu noktada dikkat çekici önemli bir bulgu da yerel yöneticilerin ilçenin mevcut turizm potansiyeli ile ilgili görüşlerini belirttikleri soru da (Tablo 10) bölgenin yeterince pazarlama yapılmamasının bölge turizmi açısından eksiklik olduğunu belirtirken, kendilerinin turizm endüstrisine en önemli katkılarının destinasyonun tanıtılması ve pazarlama alanında olduğunu belirtmeleridir.

Yerel yönetimlerin destinasyon turizmine katkıları ile ilgili bazı katılımcı görüşleri şu şekildedir:

K2 "Belediye olarak tüm birimlerimiz ve idarecilerimiz destinasyondaki turizm ile ilgili faaliyetlerde etkin bir biçimde yürütücü ya da iştirakçi olma gayretindedir. Ayrıca, konu ile ilgili diğer tüm paydaşlarla irtibat halinde olmaya çalışmakta ve verimli çalışmalar gösterme gayreti içerisindeyiz."

K9 "Kurumumuz seyahat hizmetleri ve otel işletmeciliği branşlarında eğitim vermektedir. Bugüne dek turizm endüstrisine onlarca ara eleman yetiştirme gayreti içerisinde olduk. Bundan sonra da çalışmalarımız bu yönde olacaktır."

K12 "Kurum bünyesinde görev alan akademisyenlerimiz özellikle bölgesel ve ulusal projelerde yer almaya çalışmakta, yerel halk ile üniversite öğrencilerinin uyum içerisinde olmaları konularında çalışmalar düzenlemektedir. Ayrıca, araştırmaları neticelerinde ulusal ve uluslararası literatüre Arhavi destinasyonu ile ilgili katkılar sunmaktalardır."

Araştırmaya katkı sağlayan katılımcıların destinasyonu ne derecede tanıdıkları ile ilgili değerlendirmeler Tablo 13'te yer almaktadır. Buna göre katılımcıların destinasyon ile ilgili turistik alanlara ve turizm değerlerine olan ilgi ve hâkimiyeti gözlemlenmiştir. Genel itibariyle görüş- 
me yapılan yerel yöneticilerin büyük bir çoğunluğunun bölgedeki turizm değerlerine ilişkin bilgi sahibi olduğu söylenebilir.

Tablo 13: Yöneticilerin Illçe Turizm Değerlerine Yönelik Ilgi ve Bilgisi

\begin{tabular}{|c|c|}
\hline Katılımcı & Değerlendirme \\
\hline K1 & Yaylalar hariç iyi derecede hâkim \\
\hline K2 & $\begin{array}{c}\text { Tüm destinasyonu iyi derecede bilmekte, kurum web sayfasından etkili bir biçimde destinasyon } \\
\text { bilgisi paylaşmakta }\end{array}$ \\
\hline K3 & Destinasyonu gezme şansı çok sık bulamamakta \\
\hline K4 & Birçok turistik alanı bilmekte, yerli ve yabancı misafirlere tanıtmaya çalışmakta \\
\hline K5 & Turizm değerleri hakkında yeteri derecede bilgi sahibi olduğunu düşünmekte \\
\hline K6 & Özellikle kültürel değerlere olan ilgisi sebebiyle kırsal alanlara ilgili \\
\hline K7 & $\begin{array}{l}\text { Turizme konu olabilecek her türlü değeri tanımakta, potansiyel değerleri keşif } \\
\text { çalışmaları hâlâ devam etmekte }\end{array}$ \\
\hline K8 & Özellikle yaylacılığa ilgi göstermekte, ekoturizm faaliyetlerini artırmaya yönelik çaba içerisinde \\
\hline K9 & Av turizmine ilgi duymakta, yüksek yerlerde yaşayan dağ hayvanlarını takip etmekte \\
\hline K10 & $\begin{array}{c}\text { Tüm kurum ve kuruluşların gerçekleştirdiği her türlü etkinliği haber yapmakta, yazılı ve internet } \\
\text { ortamında güncel bir şekilde paylaşmakta }\end{array}$ \\
\hline K11 & Gerek ilgisizlik, gerekse de iş yoğunluğu sebebiyle destinasyonu çok fazla bilmemekte \\
\hline K12 & $\begin{array}{l}\text { Tarihi, turistik ve kültürel değerlerin farkında olup, bu değerleri mümkün oldukça } \\
\text { gerek bireysel gerekse de kurumsal olarak ziyaret etmekte }\end{array}$ \\
\hline
\end{tabular}

Tablo incelendiğinde özellikle yerel yönetimlerin kendi ilgili alanlarına yönelik turizm türlerine ilişkin bilgi sahibi oldukları ifade edilmektedir. Katılımcıların araştırma sorularına vermiş oldukları cevaplar incelendiğinde genel olarak ilçe turizmine yönelik olumlu ifadeler ön plana çıkmaktadır. Destinasyonun sahip olduğu doğal alanlar, tarihi ve kültürel değerler, potansiyel alternatif turizm türleri gibi turizm açısından önem arz eden başlıklar katılımcıların ön plana çıkardığı konulardır. Katııımcıların dikkat çektiği diğer başlıklar ise destinasyon ile ilgili tanıtım ve tesis yetersizliği ile yerel paydaşların eşgüdüm halinde hareket etmemeleri ile ilgilidir.

\section{Sonuç ve Öneriler}

Çalışmamızın araştırma alanı olan Doğu Karadeniz, doğal, kültürel, tarihi ve turistik değerleri bünyesinde barındıran bir bölgedir. Alternatif turizm değerleri kapsamında birçok değere sahip olan Artvin ili Arhavi destinasyonu özellikle son yıllarda dikkat çeken ve talep gören bir destinasyondur. Çalışma kapsamında ilçe ile ilgili turizm alanında mülakatlar aracılığıyla derinlemesine bir çalışma yapılmış olup, ilçe yöneticilerinden endüstri ile ilgili düşünceleri alınmış, yöneticilerin ve bağlı bulundukları kurumların ilçe turizmine yönelik katkıları araştırılmıştır.

Arhavi Kaymakamı, Arhavi Belediye Başkanı, Arhavi ilç̧e Emniyet Müdürü, Arhavi İlçe Gençlik Hizmetleri ve Spor İlçe Müdürü, Arhavi Ticaret ve Sanayi Odası Başkanı, Arhavi Esnaf ve Sanatkârlar Odası Başkanı, Arhavi Folklor Kültür ve Turizm Derneği Başkanı, Arhavi Doğa Koruma Yayla Turizm Geliştirme Derneği Başkanı, Arhavi Meslek Yüksekokulu Müdürü, Arhavi Postası Gazetesi Sahibi, Arhavi Meslek Yüksekokulu Müdür Yardımcısı ve Arhavi Meslek Yüksekokulu Turizm ve Seyahat Hizmetleri Program Koordinatörü çalışmamıza konu ile ilgili fikir ve düşüncelerini paylaşarak katkı sağlamıştır.

Turistik bir bölgede yerel ölçekli hizmet veren yöneticiler, turizm endüstrisiyle ilişki içerisinde olsun veya olmasın, gerçekleşen veya gerçekleşmesi muhtemel turizm hareketlerinin gereksinimlerine ayak uydurmak durumundadır. Değerlendirmeler neticesinde, tüm katılımclların ortak fikirleri arasında Arhavi ilçe ekonomisinde turizmin önemli bir yer edinme potansiyeli olduğu görülmekle beraber, bu doğrultuda henüz gerekli adımların atılmadığı ve planlamaların gerçekleşmediği katılımcıların ortak görüşü olarak tespit edilmiştir. Katılımcıların dü- 
şüncesine göre mevcut imkânların yetersizliği, altyapı ve üstyapı çalışmalarının tamamlanmaması ilçede yer alabilecek turizm etkinliklerini azaltmakta, gelen ya da gelebilecek yerli ve yabancı turistlerin ilçede konaklama sürelerini kısaltmaktadır. Arhavi destinasyonunun Doğu Karadeniz Bölgesi'ndeki mavilik ve yeşillikten fazlasıyla pay aldığını belirten katılımcılar, ilçenin el değmemiş doğası, keşfedilmeyi bekleyen tarihi yapıları, mevcut turistik ve kültürel değerleri sayesinde dışarıdan gelebilecek insanları çekebilecek unsurlara sahip olduğunu vurgulamaktadırlar.

Arhavi ilçesinde yaşayanlar geçimlerini ağırlıklı olarak çay tarımından karşılamakla birlikte fındık ve kivi yetiştiriciliği de ilçe halkının kazanç kapılarından birini oluşturmaktadır. Bu gelir kaynaklarına, özellikle son on yıldır turizm endüstrisini de eklemek mümkündür. Sahip olduğu doğal, kültürel, tarihi ve turistik değerlerin yanı sıra, Gürcistan ile ülkemiz arasında hizmet veren Sarp Sınır Kapısına olan yakınlık, ülke genelinde Doğu Karadeniz Bölgesine var olan merak ve ilgi gibi faktörler Arhavi ilçesini bölge turizminde önemli destinasyonlardan birisi haline getirmektedir.

Özellikle son yıllarda Doğu Karadeniz Bölgesi'ne yönelik yapılan ulusal hatta uluslararası tur programlarına eklenmeye başlanan Arhavi destinasyonunun daha fazla tanıtıcı faaliyetlerle bu aktivitelerin içerisinde sık sık yer alması gerektiği konusunda hemfikir olan yerel yöneticiler, Arhavi ilçesinin güçlü yanlarını analiz ettiklerinde ilçenin bakir coğrafyası, doğası, kültürü, yöresel değerlerinin ön plana çıktıklarını belirtmektedir. Destinasyon yerel yöneticilerine göre turizm işletmelerinin yetersizliği, deniz turizminden yararlanılamaması, coğrafi şartlar gibi etkenler de ilçe turizminin zayıf yönleri arasında yer almaktadır. İlçede yer alan Mençuna Şelalesi, Çifteköprü, Ciha Kalesi, Kamilet Vadisi, Uluslararası Arhavi Kültür ve Sanat Festivali, Arhavi yaylaları ve köyleri gibi değerler ilçenin turizm anlamında fırsatları olarak göze çarparken, turizm bilincinin tam olarak oluşmaması ve nitelikli işgücü eksikliği ilçe turizmi açısından tehdit olarak dikkat çekmektedir.

Ulaşılan tüm bu bilgiler doğrultusunda, Arhavi ilçesinde hizmet veren yerel paydaşlara, faaliyet gösteren turizm işletmelerine ve benzer çalışmalar için araştırmacılara öneriler sunulmaktadır.

\section{Yerel Paydașlara;}

Illçede özellikle turizm konusunda hizmet veren yerel yöneticilere, sivil toplum kuruluşlarına, mesleki birlik ve odalara Arhavi destinasyonundaki turizm faaliyetlerinin çoğalması, yerli ve yabancı ziyaretçi oranının artması yönünde önemli görevler düşmektedir. İlgili paydaşlar, Arhavi ilçesinin doğal, kültürel, tarihi ve turistik değerlerin bilincinde olmalı, turizm unsurlarının bilinirliğini artırıcı organizasyonlar içerisinde yer almalıdır. Destinasyon ile ilgili bölge, ülke ve dünya çapında ilgi görecek, fark yaratacak çalışmalar gerçekleştirilmeli, konu ile ilgili bölgesel kurumlardan (kalkınma ajansları, proje ofisleri vb.) destek alınmalıdır.

\section{Turizm Isşletmelerine;}

Arhavi turizminin tanıtımı ve bilinirliğini artırmak adına bölgede faaliyet gösteren turizm işletmelerine büyük görev düşmektedir. Destinasyona gelen yerli ve yabancı ziyaretçilerin geceleme sayılarının artırılması, yeme-içme seçeneklerinin çoğaltılması, ulaşım hizmeti olanaklarının fazlalaştırılması, bu alanlarda hizmet veren işletmelerin gerçekleştirilmesi gereken uygulamalardır. Turizm işletmeleri ile doğrudan ve dolaylı olarak turizm endüstrisinde yer alan diğer işletmelerin işbirliği içerisinde olmaları, ortak faaliyetler içerisinde bulunmaları gerekmektedir. 


\section{Araștırmacılara;}

Birçok turizm türünün uygulanması adına elverişli alan ve özelliklere sahip Arhavi, alternatif turizm anlamında bölgenin etkili destinasyonlarındandır. Fakat ulusal ve uluslararası literatürde Arhavi ilçesi ve turizm başlıklarının bir arada değerlendirildiği çalışmalara pek rastlanılamamaktadır. Doğu Karadeniz ve Artvin genelinde, Arhavi özelinde değerlendirilen bilimsel çalışmaların nitelik ve nicelik açısından artırılması gerekmektedir. Destinasyonda yer alan tüm paydaşların (mülki idare amirlikleri, yerel yönetimler, turizm işletmeleri, meslek birlikleri ve odalar, eğitim kurumları, turistler, turizm çalışanları, yerel halk, sivil toplum kuruluşları) içerisinde bulunduğu ortak çalışmaların artırılması gerekmektedir. Arhavi ilçesinin turizm değerlerini, taleplerini, sorunlarını ve çözüm önerilerini ön plana çıkartacak araştırmaların, ulusal hatta uluslararası boyutlara taşınması için çaba gösterilmelidir.

Arhavi destinasyonunun önümüzdeki yıllarda Doğu Karadeniz'in etkili bir turizm ve cazibe merkezi olacağı yerel yöneticilerin ortak fikridir. Botanik turizmi, ekoturizm, gastronomi turizmi, spor turizmi, gençlik turizmi, kırsal turizm, üçüncü yaş turizmi, kış turizmi, kamp ve karavan turizmi, festival turizmi, kültür turizmi gibi alternatif turizm türleri kapsamında birçok değeri bünyesinde barındıran Arhavi ilçesi bölge turizmi açısından öne çıkan destinasyonlardan biridir. Önemli olan bu değerlerin planlı ve programlı bir biçimde yerel, bölgesel, ulusal hatta uluslararası tanıtımını yapabilmek, pazarlamasını sağlayabilmektir. Bu konuda yerel yöneticilere önemli işler düşmektedir. Araştırmamıza katılan yerel yöneticilerin bu konudaki olumlu ve iyi yöndeki düşünce ve niyetleri Arhavi destinasyonunun geleceği açısından önem arz eden konulardır. 


\section{Eskişehir Osmangazi Üniversitesi IïB Dergisi}

\section{Kaynaklar}

Akay, Hale (2016), Yerel Yönetimlerde Katılımcı Mekanizmalar ve Süreçler, Yerel Yönetimler İçin Dezavantajı Grupların Katılımıyla İnsan Hakları Temelli Programlama Projesi, İstanbul: Türkiye Avrupa Vakfı.

Akıllı, Hüsniye (2004), “Ekoturizmin Sosyo Kültürel, Ekonomik, Yönetsel ve Çevresel Etkiler Bakımından İrdelenmesi; Antalya Köprülü Kanyon Milli Parkı Örneği”, Yayınlanmamış Yüksek Lisans Tezi, Akdeniz Üniversitesi Sosyal Bilimler Enstitüsü.

Akyol, Ceyhun (2011), Arhavi'nin Turizm Potansiyeli, 39. Uluslararası Arhavi Kültür ve Sanat Festivali Paneli Notları, Arhavi, Artvin.

Akyol, Ceyhun; Güner, Sinan; Oğan, Yener; Aydın, Ekrem; Yüce, Rahime; Uluyurt, Tuncay (2014), “Kırsal Alanların Turizm Potansiyelinin Belirlenmesi-Artvin İli Arhavi İlçesi Örneği”, Atatürk Üniversitesi Sosyal Bilimler Enstitüsü Dergisi, C. 18, S. 2: 249-271.

Alataş, Mevlüt; Batan, Nevzat; Ezer, Tülay (2018), “Kamilet Vadisi (Artvin, Türkiye) ve Çevresindeki Epifitik Briyofitlerin Hayat Formları, Yaşam Stratejileri ve Ekolojik Özellikleri”, Anadolu Briyoloji Dergisi, C. 4, S. 1: 8-16.

Albeni, Mesut; Ongun, Utku (2005), “Antalya Turizminin Türk Turizmi İçerisindeki Yeri ve Krizlerin Antalya Turizmi Üzerindeki Etkileri”, Süleyman Demirel Üniversitesi iktisadi ve Idari Bilimler Fakültesi Dergisi, C. 10, S. 2: 93-112.

Alyakut, Baver (2007), "Sivil Toplum Kuruluşlarında Stratejik Yönetim Süreci ve Sivil Toplum Kuruluşlarında Stratejik Yönetim Uygulamalarının İncelenmesine Yönelik Bir Alan Araştırması", Yayınlanmamış Yüksek Lisans Tezi, İstanbul Üniversitesi Sosyal Bilimler Enstitüsü.

Arslan, Güzin (1990), “Koruma Planlamasında İlk Aşama; Tespit ve Tescil”, Kültür ve Tabiat Varlıklarını Koruma Kurultayı, 14-16 Mart, Kültür Bakanlığı Kültür ve Tabiat Varlıklarını Koruma Genel Müdürlüğü, Ankara, Türkiye.

Artvin İl Kültür ve Turizm Müdürlüğü (2018), Müdürlük Temmuz Brifingi.

Artvin Valiliği (2018), Artvin, İl Kültür Turizm Müdürlüğü, Artvin: Artvin Valiliği.

Aydın, Ekrem; Selvi, Murat (2012), "Kırsal Turizm Tanıtımında Yerel Paydaşların Rolü: Arhavi Örneği”, Uluslararası Sosyal ve Ekonomik Bilimler Dergisi, C. 2, S. 2: 133-144.

Baycan, Süleyman (2017), "Yerel Yönetimler ve Turizm”, 3. Turizm Şûrası, 1-3 Kasım, Kültür ve Turizm Bakanlığı, Ankara, Türkiye.

Bozok, Düriye; Kaya, Çisem; Açıksözlü, Övgü (2014), “Alanya'nın Engelli Turizmine İlişkin Durumunun Belirlenmesine Yönelik Bir Çalışma”, 15. Ulusal Turizm Kongresi, 13-16 Kasım, Gazi Üniversitesi Turizm Fakültesi, Ankara, Türkiye.

Böhm, Anja (2008), The SWOT Analysis, Norderstedt: GRIN Verlag.

Çeken, Hüseyin (2008), "Turizmin Bölgesel Kalkınmaya Etkisi Üzerine Teorik Bir İnceleme”, Afyon Kocatepe Üniversitesi Iktisadi ve Idari Bilimler Fakültesi Dergisi, C. 10, S. 2: 293-306.

Çekül (2012), Tarihi Kentler Birliği Yayınları Kılavuz Kitapçıklar Dizisi 1, Çevre ve Kültür Değerlerini Koruma ve Tanıtma Vakfı, Gaziantep: Ebat Ofset.

Çetin, Sefa (2008), "Kamu Sektöründe Stratejik Planlama: Türkiye'de İ Özel İdarelerinde Bir Araştırma”, 1. Ulusal Yerel Yönetimler Sempozyumu, 23-24 Ekim, Sakarya Üniversitesi İktisadi ve İdari Bilimler Fakültesi, Sakarya, Türkiye.

Dede, O. Murat; Güremen, Lale (2010), "Yerel Yönetimlerin Turizm Sektörü İçindeki Önemi, Rolleri ve Görevleri", Çağdaş Yerel Yönetimler, C. 19, S. 4: 47-61.

Erkuş, Adnan (2009), Davranış Bilimleri Için Bilimsel Araştırma Süreci, 2. Baskı, Ankara: Seçkin Yayıncılık.

Gillham, Bill (2005), Research Interviewing, England: Open University Press.

Güler, G. Emel (2017). "Yerel Yönetimlerin Destinasyon Markalaşmasındaki Rolü”, 3. Turizm Şûrası, 1-3 Kasım, Kültür ve Turizm Bakanlığı, Ankara, Türkiye.

Gürsoy, Sena (2006), “Merkezi İdare ve Yerel Yönetimler Açısından Bölgesel Turizm Planlaması”, Yayınlanmamış Yüksek Lisans Tezi, Ankara Üniversitesi Sosyal Bilimler Enstitüsü.

Jeffries, J. David (2007), Governments and Tourism, Oxford: Butterwoth-Heinemann.

Kalaycıoğlu, Ozan (2017), "Balıkesir İli Yerel Yöneticilerinin Turizme ve Balıkesir Turizm Potansiyeline Bakış Açıları", Yayınlanmamış Yüksek Lisans Tezi, Balıkesir Üniversitesi Sosyal Bilimler Enstitüsü.

Karasar, Niyazi (2009), Bilimsel Araştırma Yöntemi, 19. Baskı, Ankara: Nobel Yayın Dağıtım.

Kaya, Zekayi (2009), "Ulusal, Bölgesel ve Kırsal Kalkınmada Yerel Yönetimlerin Rolü”, Ulusal Kalkınma ve Yerel Yönetimler -1-, 19-20 Ekim, Türkiye ve Orta Doğu Amme İdaresi Enstitüsü, Ankara, Türkiye. 
Koçak, Abdullah; Arun, Özgür (2006), "içerik Analizi Çalışmalarında Örneklem Sorunu”, Selçuk Üniversitesi Iletişim Fakültesi Akademik Dergisi, C. 4, S. 3: 21-28.

Koday, Zeki; Koday, Saliha; Kaymaz, K. Çağlar (2015), “Mençuna Şelalesi'nin Sürdürülebilir Ekoturizm Planlaması Açısından Değerlendirilmesi", (Ed. Serhat Zaman; Ogün Coşkun), Coğrafya'ya Adanmış Bir Ömür Prof. Dr. Hayati Doğanay, Ankara: Pegem Yayıncılık: 215-237.

Küçük, Müşerref; Güneş, Gül (2013), "Yerel Kalkınmada Bir Etken Olarak Turizm: Yerel Sivil Toplum Kuruluşlarının Görüşleri”, Çağdaş Yerel Yönetimler, C. 22, S. 4: 23-50.

Kültür ve Turizm Bakanlığı (2018), "Yatırım ve Genel Müdürlüğü", http://yigm.kulturturizm.gov.tr/TR,72942/turizmgelir-gider-ve-ortalama-harcama.html., Erişim: (21.10.2018).

Long, Jonathan (1994), "Local Authority Tourism Strategies - A British Appraisal", The Journal of Tourism Studies, Vol. 5, No. 2: 17-23.

Mil, Burak (2007), “Nitel Araştırma Tekniği Olarak Görüşme”, (Ed. Atila Yüksel; Burak Mil; Yasin Bilim), Nitel Araştırma, Ankara: Detay Yayıncılık: 3-26.

Mkhonta, B. Patrick (2007), "Local Government in Swaziland: Requirements for Competent Administration in Urban Areas", Unpublished Doctoral Dissertation, Pretoria University, https://repository.up.ac.za/bitstream/handle/ 2263/29481/Complete.pdf?sequence = 9, Erişim: (12.08.2018).

Özaydın, Mehmet (2016), Artvin Ansiklopedisi Cilt 1, İstanbul: Göksu Matbaa.

Özçakmak, Ali İmdat (2014), Dünden Bugüne Arhavi, İstanbul: ISTAD Kültür Yayınları.

Rubin, Allen; Babbie, R. Earl (2009). Essential Research Methods for Social Work, $2^{\text {nd }}$ Ed., Boston: Cengage Learning.

Simpson, C. Murray (2008), "Community Benefit Tourism Initiatives-A Conceptual Oxymoron?", Tourism Management, No. 29: 1-18.

Şencan, Hüner (2005), Sosyal ve Davranışsal Ölçümlerde Güvenilirlik ve Geçerlilik, Ankara: Seçkin Yayıncllık.

Tortop, Nuri; Aykaç, Burhan; Yayman, Hüseyin; Özer, M. Akif (2014), Mahalli Idareler, 3. Baskı, Ankara: Nobel Akademik Yayıncılık.

Toskay, Tunca (1983), Turizm Olayına Genel Yaklaşım, İstanbul: Der Yayınları.

Türkay, Oğuz (2014), Destinasyon Yönetimi: Yönetimbilim Bakış Açısıyla Iş̧levler, Yaklaşımlar ve Araçlar, Ankara: Detay Yayıncılık.

Ulusoy, Ahmet; Akdemir, Tekin (2017), Mahalli Idareler, 10. Baskı. Ankara: Seçkin Yayıncılık.

UNWTO (2017), "World Tourism Barometer", Volume 15, http://www.e-unwto.org/ doi/pdf/10.18111/ wtobarometereng.2017.15.3.1, Erişim: (16.09.2018).

UNWTO (2016), "Tourism Highlights", http://www.e-unwto.org/ doi/book/10.18111/ 9789284418145, Erişim: (16.09. 2018).

Visser, Gustav (2007), "Festival Tourism in Urban Africa: The Case of South Africa”, (Ed. Christian M. Rogerson, Gustav Visser), Urban Tourism in the Developing World: The South African Experience, New Jersey: Transaction Publishers: 101-126.

Yıldırım, Ali; Şimşek, Hasan (2011), Sosyal Bilimlerde Nitel Araştırma Yöntemleri, 8. Baskı, Ankara: Seçkin Yayıncılık.

Yıldız, Seçkin; Bektaş, Fatih (2019), "Rekreatif Bir Etkinlik Olarak Turizm Cazibe Merkezi Ziyaretçilerinin Özçekim Motivasyonları", AÇÜ Uluslararası Sosyal Bilimler Dergisi, C. 5, S. 2: 187-204.

Yüksel, Emrah (2016), "Kamilet Vadisi (Arhavi) Flora ve Vejetasyonu”, Yayınlanmamış Doktora Tezi, Artvin Çoruh Üniversitesi Fen Bilimleri Enstitüsü. 


\section{Extended Summary}

\section{A Research on Local Administrators' Thoughts about Region Tourism: Artvin - Arhavi Example}

There are many influential actors in the tourism industry. Local governments are among the most important of these actors. Local governments have an important position within the industry in terms of protecting the interests of institutions and organizations operating within the industry and being the best known locals. Local contributors to the industry in creating local-scale tourism products such as raising tourism awareness in the region, diversifying tourism, improving infrastructure and superstructure services, focusing on promotion and marketing activities, increasing qualified workforce and service quality, local handicrafts, organic food, giftware production. Administrations play a participatory role in the development of tourism on a local scale. Within the framework of today's management approach, the tourism industry has become an area especially attracted by local governments. There are many studies conducted by local administrators in tourism, which have a direct impact on local development, both in cooperation with their own institutions and with other institutions. The promotion and communication issues related to tourism, which are supported by different disciplines such as culture, art, sports, education, environment and health, take place effectively with the support of other institutions. In addition, the success of services in areas such as education, health, sports, culture and tourism, which concern an entire region, depends on the participation of all stakeholders.

When the tourism-themed studies for the Arhavi destination are examined in the national and international literature, the views, thoughts and evaluations of the local administrators in the region, and the contributions of the institutions they work in, are also emphasized on what can be done for the development of the regional tourism. On the other hand, there are not many studies on the field and subject of research in national and international literature. The fact that there are few studies about determining the local administrators' point of view towards the tourism industry and the issues that can be done about the development of the regional tourism, and the fact that there has not been any study related to the research subject in the Arhavi destination reveals the original aspects of the research.

As a research area, $80 \mathrm{~km}$ from the districts of Artvin, which has been observed in recent years, as well as the development of the local government and the provincial tourism industry, has developed. Arhavi district was selected and local administrators working in the district were preferred as participants. In the research, the opinions of local administrators in Arhavi district, which is determined as the study area, were taken about tourism, their thoughts were evaluated, the functions of themselves and the institutions they work in in district tourism were emphasized, and their suggestions for developing tourism in the destination were included. In the study, the maximum diversity sampling method, which is one of the purposeful sampling methods in qualitative research, was used. Local administrators to whom interviews were conducted; district governor, mayor, chief of police, youth services and sports manager, head of chamber of commerce and industry, head of shopkeepers and craftsmen, head of folklore culture and tourism association, head of nature conservation highland tourism development association, head of vocational school, local newspaper owner, profession consists of the director of the school, vice principal and vocational school tourism and travel services program coordinator.

Managers serving locally in a touristic region must keep up with the needs of tourism movements, whether or not they are related to the tourism industry. As a result of the evaluations, although it is seen that tourism has an important place in the economy of Arhavi district among the common ideas of all participants, it has been determined as the common opinion of the participants that the necessary steps have not yet been taken and the plans have not been realized in this direction. According to the opinions of the participants, the insufficiency of the available facilities and the incomplete infrastructure and superstructure works reduce the tourism activities that may take place in the district, and shorten the stay of the domestic and foreign tourists in the district. Stating that the Arhavi destination has a lot of blue and green in the Eastern Black Sea Region, the participants emphasize that the county has untouched nature, historical structures waiting to be discovered, and attractions that can attract people who can come from outside thanks to its current touristic and cultural values.

Although the people living in Arhavi district mostly cover their livelihoods from tea agriculture, hazelnut and kiwi cultivation is one of the earning gates of the district people. It is possible to add the tourism industry to these sources of income, especially in the last decade. Besides the natural, cultural, historical and touristic values it possesses, the proximity to Sarp Border Gate, which serves between Georgia and our country, factors such as curiosity and interest in the Eastern Black Sea Region throughout the country make Arhavi district one of the important destinations in the tourism of the region. 
It is seen that the Arhavi destination has been added to the national and international tour programs made especially for the Eastern Black Sea Region in recent years. Local administrators, who agree that their respective destination should be included in these activities frequently with more introductory activities, state that the virgin geography, nature, culture and local values of the district come to the fore when they analyze the strengths of the Arhavi district. According to destination local administrators, factors such as insufficiency of tourism enterprises, inability to benefit from sea tourism, and geographical conditions are among the weaknesses of district tourism. While the values such as Mençuna Waterfall, Çifteköprü, Ciha Castle, Kamilet Valley, International Arhavi Culture and Art Festival, Arhavi plateaus and villages in the district stand out as opportunities for tourism in terms of tourism, lack of tourism awareness and lack of qualified workforce are considered as a threat for district tourism attract.

It is the common idea of local administrators that the Arhavi destination will be an effective tourism and attraction center of the Eastern Black Sea in the coming years. Arhavi district, is one of the destinations which has many values in terms of alternative tourism types such as botanic tourism, ecotourism, gastronomy tourism, sports tourism, youth tourism, rural tourism, third age tourism, winter tourism, camping and caravan tourism, festival tourism, cultural tourism, stands out in terms of regional tourism. The important thing is to be able to promote and market these values locally, regionally, nationally and even internationally in a planned and programmed way. Local administrators have important jobs in this regard. The positive and good thoughts and intentions of local administrators participating in our research are important issues for the future of Arhavi destination. 
Eskişehir Osmangazi Üniversitesi IißBF Dergisi 